\title{
THE SECRET SOUTH AFRICAN PROJECT TEAM: BUILDING STRIKE CRAFT IN ISRAEL, 1975-79 ${ }^{1}$
}

\author{
Cdr Thean Potgieter \\ Subject Group Military History \\ Faculty of Military Science, Stellenbosch University
}

\section{Introduction}

Though the history of the South African Navy (SAN) only dates back to 1922, for most of its history it depended on Britain for warships. The British Royal Navy on the other hand had an unbroken involvement with maritime defence along the South African Coast and the protection of the Cape Sea Route from 1806 to 1975 (when the Simon's Town Agreement was cancelled). However, political tension between South Africa's apartheid government and Britain caused a break in this relationship, forcing the SAN to acquire warships from alternative sources.

A number of South African efforts to acquire corvettes failed during the 1970 s, leaving the strike craft project as the only major warship project of the SAN to succeed for close to three decades. This project had an overseas as well as a local building phase. As part of the overseas phase, a project team was dispatched to Israel in 1975 to oversee the building and commissioning into the SAN, of three strike craft. The project team consisted of the Armaments Board (AB, Armscor after 1977) team as well as the SAN project team. While the AB/Armscor had to oversee the building process, the SAN team had to prepare to take the vessels into service.

As a result of the international condemnation of South Africa's apartheid policy, many countries refused to sell armaments to South Africa and the United Nations (UN) instituted a series of restrictions against South Africa. The strike craft project therefore had to take place under a veil of secrecy and the establishment of a

1 The term "secret" in the title refers to the classified nature of the project during and after its execution. As a result, special permission was gained to publish the article. The author wishes to express his gratitude to the following naval officers for their assistance and for commenting on the draft: the Chief of the SA Navy, Vice Admiral J.F. Retief, Rear Admiral (JG) A.G. Söderlund and Captain (SAN) P.G. Retief. 
project team in Israel was a clandestine undertaking. This caused a considerable amount of difficulties for the project team. Nonetheless, the project was successfully completed and the first warships (strike craft) armed with missiles and sophisticated electronic warfare systems entered service with the SAN.

Due to little interest in the military-industrial history of South Africa as well as its classified nature, South African historians seldom study such themes. The history of the strike craft project was highly classified and as a result the relevant archival sources were not previously utilised for the purpose of publication. This article is therefore an endeavour to 'tell the story' of this project and to discuss some of the difficulties that were associated with vessel acquisition at the time. Though reference will be made to the international political situation, the article is about the strike craft-building project in Israel and the experience of living and working covertly - in other words the industrial, administrative, security and social aspects, rather then the underlying politics of the day - is the focus. As the article was mainly compiled from relevant official documents and with the assistance of many of the role players involved, it primarily deals with the topic from that point of view.

As far as the financial aspects of the strike craft projects are concerned, it is beyond the scope of this paper to discuss it. Much overspending took place on the programme as a whole, but due to its complex financial history, it is difficult to just report on the cost of the overseas building phase. Funds transferred to Israel would also include payments for licensing fees, assistance with the local building phase and the creation of shore facilities in South Africa. Much was learnt concerning financial planning for a complex warship-building project, as the efficient financial management of subsequent strike craft programmes indicate. Finally, though the complex and interesting financial and management history of the strike craft projects are not the aim of this article, it warrants separate investigation.

\section{Vessel Requirement of the South African Navy and the Inception of the Strike Craft Project}

The South African Navy was created in April 1922, after three small, former British, vessels were commissioned into a new arm of the Union Defence Force, called the South African Naval Service (SANS). These three vessels were decommissioned in 1933-34 as a result of the depression and only a skeleton staff remained until the outbreak of Second World War in September 1939. With no warships available the SANS (later to become the Seaward Defence Force - SDF) had to requisition ships from trade, mainly whaling and fishing, and convert them into anti-submarine vessels and minesweepers. These little ships and their crews served with distinction throughout the Second World War, both in local waters as 
well as in the Mediterranean. South African sailors and their ships gained much praise and respect for their devotion to duty and service.

The South African Naval Forces (SANF - restructured in 1942) received its first purpose-built warships, three frigates of the Loch class, from Great Britain in 1944-45. In addition, the South African Navy (SAN - renamed in 1951) commissioned two former Royal Navy ocean minesweepers in 1947 and also bought two Second World War destroyers from Britain in 1950 and 1953. ${ }^{2}$ Britain still maintained a strong naval presence in South Africa, as the protection of the Cape Sea Route was very important for Britain and the West during the Cold War era. In 1955 Britain and South Africa concluded the so-called Simon's Town Agreement essentially a policy declaration emphasising regional co-operation and defence against external aggression with the purpose of securing the safety of the Cape Sea Route. The SAN took over the control of the naval base at Simon's Town and received a wider operational responsibility in the South Atlantic (essentially a "paraNato" role, without calling it that), while Britain retained the privilege of using the base and its facilities. ${ }^{3}$

An important outcome of the Agreement was the expansion and modernisation of the SAN - it acquired four frigates, five seaward defence boats and ten minesweepers from Britain. The frigates were one Type 15 (converted "W" class destroyer) and three Type 12 anti-submarine frigates. The Type 12 frigates were the first major warships ordered and built for the SAN. South Africa now had a medium sized, typically Western navy, strongly aligned to the Royal Navy. In terms of its role, equipment, training and doctrine it was a small version of the Royal Navy, more suited for the requirements of Britain than for the indigenous and unique maritime defence requirements of South Africa.

International condemnation of South Africa's apartheid policy gained much momentum during the sixties. With the decolonisation process in full swing, many new states joined the international community and called for sanctions against South Africa. As a result the $\mathrm{UN}$ accepted a number of restrictive resolutions on weapon sales to South Africa from 1963 onwards. The relationship between South Africa and Britain also became problematic. South Africa left the British Commonwealth in 1961 and the British Labour Government (elected in 1964) prohibited weapons sales to South Africa, though they honoured contracts that formed part of the

2 See T.D. Potgieter, Die Geskiedenis van Projek Japonica en die Missielbootprojekte, 1968-87 (Unpublished MA, RAU, 1992), p.20.

3 Armscor Archive, Pretoria (hereafter AA). RSA Verdragreeks no 2/1955, Ooreenkoms tussen Suid-Afrika en Verenigde Koninkryk betreffende Verdedigingsaangeleenthede, p.3 and R.A. Edwards (Vice Admiral (ret) and former Chief SAN), interview, June 2001. 
Simon's Town agreement. In June 1967, after a British cutback in overseas military commitments (the so-called "east of Suez" withdrawal), the Royal Navy withdrew its last frigate that was "on station" in Simon's Town.

Despite the fact that the Simon's Town Agreement remained unchanged during the sixties, it was not to last. It became a political liability for Britain, while South Africa thought that it received nothing in return for its unilateral effort of keeping the naval base available to Britain. When the Agreement was cancelled in June 1975, it brought the British naval presence of more than a century and a half in South Africa to an end. Without the helping hand of "Big Brother" Royal Navy, the SAN was now truly "on its own". Operationally the SAN needed ships to patrol the South African and South West Africa/Namibia coasts, guard the Cape Sea Route and, within the framework of the Cold War, shadow Soviet vessels that rounded the Cape of Good Hope,${ }^{4}$ but assistance from Britain would not be forthcoming.

The SAN commenced with a planning process for a fleet upgrade in the late sixties. It investigated its future role and tried to match it to the type of equipment needed to be a credible maritime force. It's ageing fleet of destroyers and frigates had to be upgraded and submarines were deemed necessary. The SAN concluded (extremely optimistically) that it would require up to ten light frigates and/or corvettes during the last three decades of the $20^{\text {th }}$ century! ${ }^{5}$ These ships had to be well armed and big enough for adequate sea keeping and endurance in the oftenstormy South African waters. ${ }^{6}$ Compact warships of roughly between one and two thousand tons, armed with guns and missiles, were deemed ideal. ${ }^{7}$ Six "patrol vessels" were the requirement of a future acquisition programme and South Africa had to consider building its own "light frigates" in the future. ${ }^{8}$

In March 1971 a South African project team visited Britain, France and Portugal to investigate alternative designs for future frigates or corvettes. Buying from Britain was politically out of the question, but France was building submarines

4 Military Archive Depot Pretoria (hereafter MAD). VSH10/66/10/2, Notule van Vergadering te Simonstad in sake Projek Taurus, 24 January 1972, p.7.

5 MAD. VSH10/66/10/2, Die verwagte rol en taak van die Vloot 1970-1980-1990-2000.

6 MAD. VSH10/38/3/1, Memorandum. Stafvereistes Kuspatrollievaartuie, 28 October 1969.

7 Opinions regarding the ideal vessel for South African sea conditions vary. Good sea keeping and endurance were emphasised in official documentation, which at this stage implied a ship of at least 1200 ton and $84 \mathrm{~m}$ in length. The Taurus staff requirement was for a ship of at least 1800t. See Potgieter, Die Geskiedenis van Projek Japonica en die Missielbootprojekte, 1968-87, p.33.

8 AA. Minutes of Armscor Board of Directors Meeting number 6, 3 February 1969 and MAD. VSH10/66/10/2, Notule van Vergadering te Simonstad in sake Projek Taurus, 24 January 1972, p.7. 
for South Africa (three Daphné class submarines delivered between 1970 and 1972) and Portugal was also prepared to sell corvettes to South Africa. ${ }^{9}$ French designs were impressive, but too expensive, while in Portugal the team inspected a much cheaper, smaller and slower Portuguese 1400-ton corvette of the Joao Couthinho class. ${ }^{10}$ Since Angola and Mozambique were still Portuguese colonies, South Africa regarded Portugal as an ally in Africa. Hence, the South African Minister of Defence, P.W. Botha, wanted to purchase the ships from Portugal with the intention of supporting Portugal financially. ${ }^{11}$ It was a deal. The Spanish shipyard Bazan would act as the main contractor, while a Portuguese yard would be the subcontractor and build the ships.

A project team (Project Taurus) was established in Lisbon in February 1972. But as the SAN wanted more than the basic Joao Couthinho design and decided to improve the design and upgrade its weapon systems. This resulted in the ships becoming bigger and more expensive, while the completion date of the project study phase was postponed. Due to the rising cost, it was clear by September 1973 that only three, instead of six ships, could be built. Contract negotiations didn't commence immediately after the completion of the final vessel requirements (end of 1973) and it soon became clear that the tenders would not be finalized before November 1974 - which yet again would delay the project for another year. ${ }^{12}$ These setbacks were attributed to a lack of support from the Portuguese Navy, the SAN's constant changes to the basic design and the poor ability of the SAN and Armaments Board (AB) to design ships and do proper cost analysis. The ship therefore "grew" in size (from 1300 tons to 1800 tons) and price, while time was running out! ${ }^{13}$

In the end Project Taurus was cancelled due to the changing political climate in Portugal. After the bloodless coup d'etat in 1974, Portugal immediately granted independence to its colonies in Africa. South Africa was notified that Portugal would no longer continue with the project. Due to all the delays, the project therefore ended before any contracts could be finalised. ${ }^{14}$

9 A.K. du Toit, South Africa's Fighting Ships: Past and Present (Ashanti, Johannesburg, 1992), p.176.

10 AA. Produksievorderingsverslag vir ses maande, 30 September 1971, pp.15-16.

11 MAD. VSH10/66/10/2, Aankoop van 6 korvette van Portugal. See also AA. Memorandum 55/24, 2 December 1971, attached to Minutes of Board of Directors of the Armaments Board, nr. 55, p.107.

12 AA. K5/19/1/12, Memorandum 75/28, 14 February 1974 and Armaments Board Yearly Report nr. 10, 1973-74, p.20.

13 AA. Minutes of Board of Directors of the Armaments Board, nr. 78, 8 May 1974, p.11.

14 AA. Minutes of Board of Directors of the Armaments Board, nr. 79, 27 June 1974, pp.4-5. 
Meanwhile, the then Minister of Defence (P.W. Botha) was very perturbed about the delays on Project Taurus and already, before the final cancellation of Project Taurus, opened negotiations with Israel to acquire six missile strike craft. He notified the President of the Armaments Board of his intention on 17 April 1974, while only mentioning it to Cabinet in June 1974. ${ }^{15}$ Botha was emphatic that the project must be executed speedily, hence the conclusion of a "package deal" and his insistence on personally approving all deviations from the original design. ${ }^{16}$

As both South Africa and Israel to some extent shared a pariah status, and many countries were not prepared to sell weapons to South Africa, it was clear that both countries could gain from military co-operation. Though South Africa had a growing armaments industry, it lacked know-how in various fields, which made Israeli assistance valuable. Also as South Africa later became embroiled in the conflict on the South West Africa/Namibia-Angola border region and in the Angolan Civil War, its armaments industry needed support. On the basis of the unique position both countries found themselves in and the international situation of the time, the relationship between Israel and South Africa flourished. ${ }^{17}$

When two Israeli Reshef class strike craft rounded the Cape in March 1974, SAN officers evaluated these vessels. They were impressed by the craft and their capabilities, despite their small size. Though the Reshef (meaning "flame" in Hebrew) class strike craft, were designed and built in Israel, they were larger and an improvement on the strike craft Israel bought from France earlier.

Within the SAN, the strike craft project was a controversial one. Two schools of thought existed; the one favouring big seaworthy frigate type ships (in the tradition of the Royal Navy), while the other saw smaller strike craft armed with missiles as ideal. ${ }^{18}$ Though many naval officers considered strike craft to be a good addition to the fleet, frigates or corvettes (with a displacement of at least a 1000 to 2000 tons, good endurance and sea keeping for lengthy patrols in our turbulent coastal waters), were seen as the ideal vessels to be the Navy's major warships. Other concerns were that the strike craft had no anti-submarine sensors or weapons

\footnotetext{
15 AA. Minutes of Armaments Board Executive Committee, nr. 29, 17 April 1974, p.3 and Minutes of Armaments Board Executive Committee, nr 30, 19 May 1974, p.1.

16 AA. Minutes of Board of Directors of the Armaments Board, nr. 79, 27 June 1974, pp.2-3 and K15/46, H.J. Samuels - P.W. Botha, 30 July 1974.

17 See B. Beit-Hallahmi, The Israeli Connection: Whom Israel Arms and Why? (Taurus, London, 1988), p.117 and Potgieter, pp.89-93.

18 AA. K15/5, A critical examination of the function and composition of the SAN, May 1973.
} 
and the fact that they had a limited anti-aircraft capability. ${ }^{19}$ (See Figure 1 for the main characteristics of the Reshef class strike craft.)

\begin{tabular}{|l|l|}
\hline Displacement & 415 tons (standard) 450 tons (full) \\
\hline Dimension & Length : $58 \mathrm{~m}$ \\
& Width $: 7.8 \mathrm{~m}$ \\
& Draft: : 2,4 m \\
\hline Propulsion system & $\begin{array}{l}4 \text { MTU diesel engines producing 12000 shp } \\
4 \text { propeller shafts }\end{array}$ \\
\hline Speed & 34 knots (maximum) \\
\hline Guns & $\begin{array}{l}2 \times 76 \text { mm /68 OTO Melara } \\
2 \text { X 20 mm Oerlikon, 2 X 12,7 mm MG's }\end{array}$ \\
\hline Missiles & $\begin{array}{l}6-8 \text { X Scorpion (Gabriel Mk II) surface-to-surface } \\
\text { missiles }\end{array}$ \\
\hline Sensors & $\begin{array}{l}\text { Radar and fire control systems } \\
\text { Electronic warfare and electronic counter measures }\end{array}$ \\
\hline Complement & 8 officers and 39 crew \\
\hline
\end{tabular}

Figure 1: Characteristics of the Reshef class strike craft.

The strike craft project was designated Project Japonica. Its purpose was to build and equip six vessels: three in Israel and three in South Africa, for the SAN. The main contractor in Israel was Israel Aircraft Industries (IAI), which had to appoint a number of subcontractors to build the ships and conclude the other project activities. The main contract with IAI was signed on 21 August $1974^{20}$ and both countries agreed to keep it secret and to make no official announcements. Armscor appointed Sandock Austral in Durban as the local shipbuilder.

The Japonica programme with its subprojects was a massive undertaking. Co-ordination of the project took place from the AB/Armscor head office in Pretoria, while projects teams were established in Israel (overseas building phase) and Durban (local building phase). The programme was divided into three main projects and

19 MAD. VSH10/66/2/1, Chief SAN - Executive Manager Armaments Board, Beoogde noodsaaklike veranderings en byvoegings aan die huidige toerusting van die "Reshef" tipe missielboot, 2 July 1974.

20 AA. Register of Contracts, nr. 187. 
five related projects: The main projects were the acquisition of three vessels from Israel, the local building phase and the development of the logistic support system. The related projects were acquiring the main guns; acquisition and local production of ammunition; definition and acquisition of the external communications equipment; definition and acquisition of the electronic warfare (EW), electronic countermeasures (ECM) and identification friend or foe equipment (IFF); as well as the acquisition of the rest of the weapon systems and missiles. Inherent to the programme (main projects) was the transfer of knowledge to the shipyard and other involved South African industries and the creation of shore facilities on Salisbury Island in Durban. ${ }^{21}$

While the strike craft project was gaining momentum, the SAN still insisted that it needed corvettes as its main surface combatants as well as more submarines. As a result two corvettes (of the Aviso A69 design) and two submarines (of the Agosta class) were ordered from France in 1975. The project progressed well, but on 4 November 1977 the Security Council of the UN accepted a compulsory armaments boycott against South Africa. Unfortunately for the Navy, France cancelled both these acquisition projects at the end of November 1977. The strike craft programme was the only surviving warship project of the SAN.

In the meantime the South African Government increasingly perceived itself under threat from a total, multifaceted onslaught, but as the 1977 White Paper on Defence so aptly shows, it was committed to combat this with a total strategy. Concurrently the international isolation of South Africa increased and the compulsory armaments boycott placed emphasis on the international condemnation of South Africa's racist policies. ${ }^{22}$ As the Security Council of the UN was dominated by Western states, it also underlines the isolation from the West and the final severing of South Africa's traditional source of armaments; specifically naval vessels.

In the light of the international political atmosphere and the position of the South African Government, security on the strike craft project was a real concern. Both countries wanted the project to be kept secret in order to give it the best chance of success. Yet some information did leak - already in its 1975-76 edition the authoritative Jane's Fighting Ships announced that the building of missile corvettes was going to take place in South Africa, and later editions published full details,

21 AA. K15/46/1/9/3, Japonica Project Breakdown, Appendix A to Japonica report, 25 March 1976 and K15/46/10/1, Programme Japonica, p.4.

22 C. Alden, Apartheid's Last Stand. The Rise and Fall of the South African Security State (Macmillan, London, 1996), p.49. 
including information about the Israeli building project. ${ }^{23}$ In South Africa, P.W. Botha announced at a news conference on 6 February 1975 that six strike craft were to be built at Sandock Austral in Durban and that Salisbury Island (Durban) would be developed as a strike craft base. Newspaper reactions were favourable and Afrikaans newspapers considered it as something of national importance ("in landsbelang"). ${ }^{24}$ Reaction in Parliament was also favourable and opposition defence spokesperson, Mr W.V. Raw, supported the acquisition, as the Navy needed it. However, he warned that this should not cause the cancellation of future corvette programmes. ${ }^{25}$ The Israeli connection was never mentioned or even suggested by South African politicians or military personnel.

\section{Establishing the Project Team in Israel}

The Project Japonica team in Israel had to be established covertly, because the project was highly classified. Due to the pressing timescales, this had to take place urgently as the technical drawings and specifications had to be approved before the building phase could commence. It was hoped that the first phase (establishing the project team leader and a few other members at the shipyard in Haifa) could take place during January $1975 .^{26}$ In December 1974 the President of the AB notified the Secretary of Foreign Affairs that this project was the biggest of the armaments deals conducted with Israel and since there would be permanent South African representation in Israel, he asked if they could receive office space at the South African Consulate (the SA Embassy after 1975). Foreign Affairs replied that only temporary space could be provided. ${ }^{27}$ But, it was then decided that due to its classified nature, the project team should not be associated with South Africa and office space at the main contractor (IAI) should rather be utilised.

In January 1975 two naval officers, Commander (Cdr) J.R.W. Dart and Lieutenant Commander ( $\mathrm{Lt} \mathrm{Cdr)} \mathrm{R.D.} \mathrm{Cook} \mathrm{were} \mathrm{seconded} \mathrm{to} \mathrm{the} \mathrm{AB} \mathrm{to} \mathrm{execute}$ control over the building phase in Israel. ${ }^{28}$ In the light of all the preparations and

23 J.E. Moore (ed), Jane's Fighting Ships, 1975-6 (Macdonald \& Jane's, London, 1975), p.292 and J.E. Moore (ed), Jane's Fighting Ships, 1976-7 (Macdonald \& Jane's, London, 1976), p.400.

24 All the important regional and national papers published the story. See for example the following newspapers, The Star, Transvaler, Pretoria News, Die Burger, Volksblad, Hoofstad and Beeld, 6-7 February 1975.

25 Hansard. 22 April 1975, column 4638.

26 AA. K15/46/30/3, Memorandum Bestuurder Vaartuie (Manager Vessels) - President AB, 12 February 1975.

27 AA. D39/1, Correspondence between the President AB and the Secretary of Foreign Affairs, 19 and 23 December 1974.

28 AA. K15/46/10/1, W.Venter - Chief SAN, Projek Japonica Programsamestelling, 16 October 1974. 
administration that had to be done, the initial idea of establishing the team during January 1975 was too ambitious. In February, official approval was granted to establish the two naval officers and Mr I.O. Du Toit of the Armaments Board in Israel from 2 April onwards. In the "Settlement Plan" (completed during March) aspects relating to office accommodation, private accommodation, transport and administrative arrangement were defined. ${ }^{29}$ During April the first members of the AB team under the leadership of Cdr Dart, went to Israel, while the rest followed in the course of the year. Cdr Dart reported directly to the programme manager at the $\mathrm{AB} /$ Armscor office in Pretoria and was supported by a small staff (See figure 2):

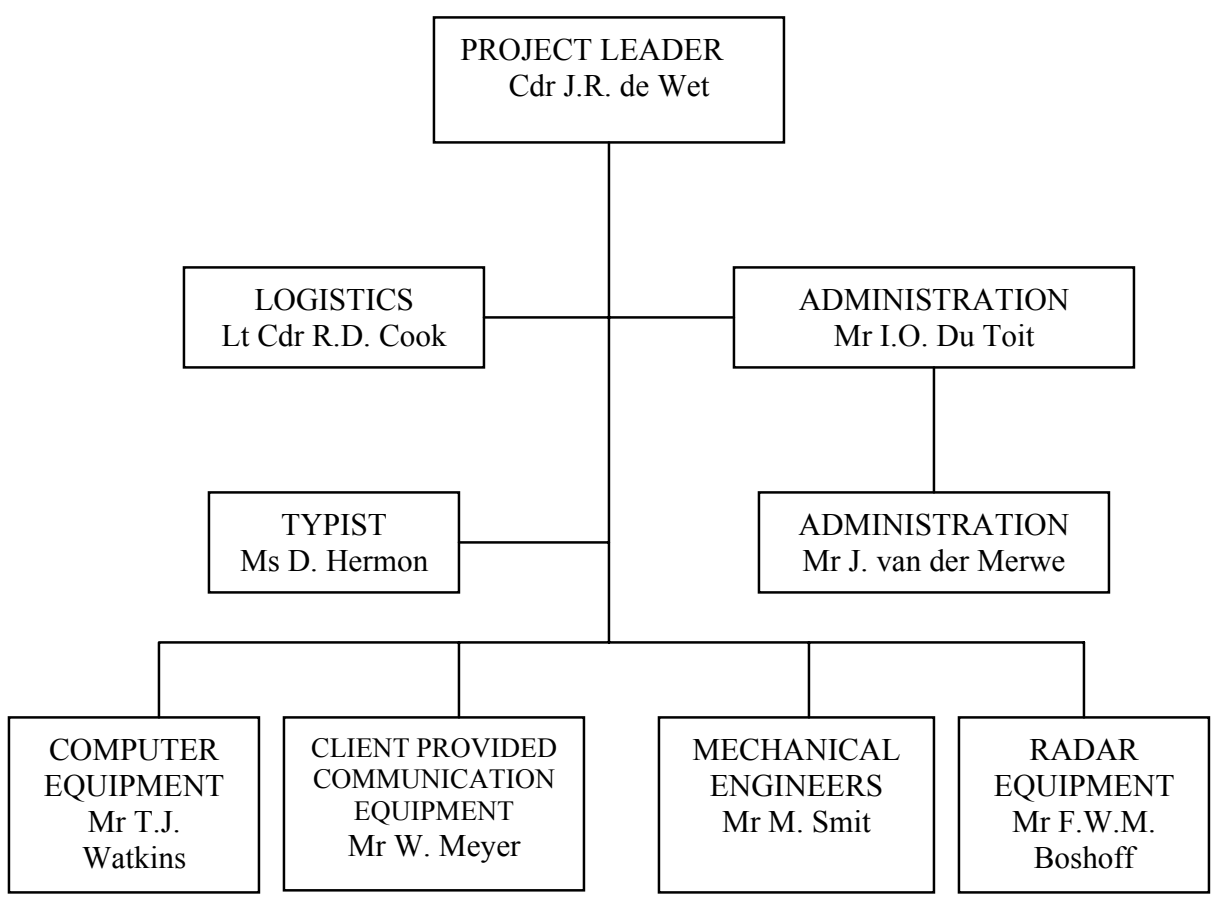

Figure 2: The structure of the Project Japonica Team of the Armaments Board in Israel, November 1976.

The responsibilities of the AB project team included the following: They had to monitor and audit the building process, work closely with the main contractor and sub-contractors, assist the contractors with the planning process and ensure that the

29 AA. K15/46/10/2, Project Japonica Settlement Plan, 24 March 1975. 
expected quality standards were maintained. Contractually their tasks ranged from the approval of drawings; inspection of materials delivered to the shipyard; observation of the building process with specific reference to the installation, integration and testing of weapons and equipment; to the conduct of acceptance trials. $^{30}$ The project team also had to provide assistance to the SAN in their negotiations with contractors in Israel and to assist with the future utilisation of the vessels they had to conduct a logistic support project aimed at managing the spares and equipment needed for maintaining the vessels. Furthermore the project team had to support the transfer of know-how for the local building project at Sandock Austral in Durban.

As the strike craft took the SAN into the missile era, it was evident that the SAN would need sufficient, well-trained crews to run and maintain the strike craft. Crews as well as shore personnel had to be trained and the only way to provide sufficient training staff, was to initially train them in Israel (training facilities would then be created in South Africa) alongside the initial crews. This was essentially the domain of the SAN. The first members of the SAN contingent in Israel (SAN in the Middle East referred to as SAMMIDE) arrived in May, while the rest followed in the course of 1975 and early in $1976 .^{31}$

SAMMIDE consisted of the strike craft crews as well as technical and administrative personnel and was under the command of Cdr J.S. Orrock. Primarily they had to ensure the proper training of naval personnel, administer the SAN personnel in Israel and find accommodation for both married and unmarried members. Training took the form of special courses presented by the Israeli Navy as well as courses organised by some of the factories that provided weapons and electronic equipment. Furthermore personnel were seconded to Israeli ships, workshops and shore facilities. ${ }^{32}$ Besides involvement in the general project progress and administration, SAMMIDE had to ensure that the vessels sail at the predetermined dates with sufficiently trained crewmembers on board and provide logistic support for the vessels. ${ }^{33}$

At its strongest the SAN contingent consisted of the crews of the three vessels (140 persons) as well as technical and administrative personnel. Many families were also in Israel (never more than 100 families) and it is estimated that at

30 AA. Contract records, Contract between Israeli Aircraft Industries Limited and the Armaments Board, 21 August 1974.

31 I.O. Du Toit (Armaments Board Israel project team member) and J.S. Orrock (Commodore (ret), Commander of SAMMIDE), interviews, 1986 and 1992.

32 R.C. Simpson-Anderson (Vice Admiral (ret), Captain of the first strike craft and former Chief of the SAN), numerous interviews, 1990 and 1992. J.S. Orrock, interview. 
its height, there were about 350 South Africans in Israel (including AB/Armscor and SAN members as well as their families). ${ }^{34}$

\section{The Building Phase and other Project Activities}

After the establishment of the first Project Japonica team members in Israel in April 1975, work immediately commenced. They had to oversee the whole process, up to the final delivery of the vessels to the SAN. The main contractor, IAI, appointed a number of subcontractors which including the shipbuilder Israel Shipyards Limited (ISL) and Elta, Elbit and MBT, who provided the weapon systems. Differences between the project team and IAI centred mainly around two themes: the quality of workmanship and the perception that IAI should put more pressure on its subcontractors (mainly ISL) to improve performance and adhere to timescales. ${ }^{35}$

Work on the hull plating for the first strike craft commenced early in 1975. When the first hull was completed a year later, the keel and bow sections of the second hull were already in place. Though the building of the hulls went according to schedule, it was clear by the middle of 1976 that final delivery targets would not be met. One of the main problems was that both the Oto Melara $76 \mathrm{~mm}$ guns as well as optical director of the first vessel were already four months late. ${ }^{36}$ The launching of the first strike craft was further delayed due to quality problems with the installation of equipment. The project team insisted that the contractors rectify these problems before the launching.

Some of the greatest differences between the South Africans and the Israeli contractors related to quality control issues. Quality of workmanship was always an issue specifically since adherence to higher standards would raise the cost for the contractor and subcontractors. The quality control emphasis was mainly on the hull, the propulsion systems and the installation of the weapon systems, where standards were often unsatisfactory. The project team were of the opinion that control by management was insufficient, which led to a very untidy working environment and often caused damage to equipment during installation. Some of the equipment then had to be replaced, which impacted on timescales. ${ }^{37}$

34 This information was deduced from an analysis of the relevant documents as well as the interviews with G. Syndercombe (Vice Admiral (ret) first Officer Commanding Strike Craft Flotilla, former Chief of the SAN), 1986; R.C. Simpson-Anderson; J.S. Orrock and Mr A.T. Dreyer (Armscor project team), 1986.

35 See Potgieter, pp.146-8.

36 AA. K15/46//1/8, Project Japonica Progress Report, 16 June 1976 and K15/46//1/8, Project Japonica Vordering, 21 October 1976.

37 AA. K15/46/1/8, Appendix to Projek Japonica verslag aan H SAV, 5 April 1977. 
The project team voiced many complaints, specifically during the building of the first vessel and put much pressure on IAI to be tougher with the subcontractors, specifically with ISL. On two occasions they withheld payments and the Naval Acceptance Group (NAG) also refused to take the ship to sea for its acceptance trials, if certain errors were not corrected first. ${ }^{38}$ Quality control on the weapon systems was generally good, which was mainly due to the higher standards at the factories that produced these systems. As a result of these problems and the constant complaints of the project team, the quality control and workmanship were better on the second and third vessels, and fewer delays were experienced. Besides the problems already mentioned, the external communication system of the first vessel was also late, causing more delay. As it had to be compatible with the systems used by the SAN, it was produced and delivered by Armscor. Integrating it with the rest of the onboard systems of the strike craft proved to be a big problem and caused much delay. ${ }^{39}$

In general however, the South Africans regarded IAI as a fair business partner. Despite the fact that its administrative processes were often cumbersome and time consuming, IAI provided much assistance to the project team and often did more than the contract stipulated. The South African's often felt that IAI were "on their side" 40 and the IAI public relations personnel did much to assist the South African's and make them feel at home.

The main contract provided for the technical training of system operators at the facilities of the contractor and subcontractors. As the SAN realised that this training in itself would be insufficient, they negotiated with the Israeli Navy (IN) to have their personnel trained at IN shore facilities, IN simulators and onboard IN vessels. Training commenced in November 1975 and it was often difficult due to language and security constraints, while textbooks and training material first had to be translated from Hebrew into English. ${ }^{41}$ Training on the vessels was "on the job training" and the IN was initially hesitant to allow more than two SAN members onboard for security reasons. As relations improved however, groups of up to seven went to sea onboard IN vessels. ${ }^{42}$ At Sharm el Sheik it was easier then at Haifa and

38 AA. CK15/46/30/5. Report by Cdr J.R.W. Dart on the Argus area of activities with respect to Project Japonica, 1 April 1975 - 30 June 1978, 12 July 1978, pp.3-4.

39 AA. K15/46/1/9/3. Projek Japonica, Vordering, Verslag ter tafel gelê by die sewende PJKK-vergadering, 21 October 1976, p.2 and T.J. Watkins (member Armaments Board project team), interview, 1986.

40 "Putsonderwater" literally meaning "well-without-water", A. Söderlund (R Adm (JG), Lt Cdr onboard the P1562 in Israel), written commentary, September 2004.

41 AA. BE9/5/1, Volume 1, Indemnity regarding training, AB and IAI, 17 October 1975 and J.S. Orrock, interview.

42 R.C. Simpson-Anderson and J.S. Orrock, interviews. 
up to eight members were stationed there at times. There was a base that had little contact with the public and SAMMIDE used a small building (with "Putsonderwater" written on it, in Hebrew) for senior members and a dormitory for the ratings. ${ }^{43}$

Initially the IN was not very keen to provide the project team with more than training and only official navy-to-navy interaction took place. Later, co-operation flourished and the South Africans received much technical support and advice from the IN. The IN also gave good assistance with the creation of the relevant shore facilities at the strike craft base on Salisbury Island. SAN officers visited the IN weapons-electronic workshop, fire control simulator, diesel workshop and missile works to acquaint themselves with the nature of such facilities and to gain information for the local project. As a result of the classified nature of the project, South African sailors could not wear SAN uniforms and during training, on visits to IN ships and onboard their own vessels they had to wear Israeli uniforms (without any rank insignia). ${ }^{44}$

In order to run and maintain strike craft, the project team had to create the relevant documentation and handbooks. This was a massive undertaking since the material had to be translated from Hebrew into English and edited. Technical terms proved to be a problem and in the editing process they had to keep to terms that South African users would be acquainted with. Furthermore, a complete computerised database of all spare parts was created in order to effectively manage onboard and shore spare parts stores. To this end the project team had to both order spare parts for the onboard storage as well as order and dispatch sufficient spare parts for the maintenance and service of the strike craft in South Africa. Due to all these efforts equipment and parts were received and indexed timely, with the result that the strike craft could be properly maintained from the beginning. ${ }^{45}$

With the transfer of knowledge and know-how for the local building process, the project team faced unique challenges. Obtaining enough technical information and drawings posed constant problems. The Israeli builders did much of the work without proper drawings and technical specifications as they often "just knew how to", due to their experience. When the project team did receive drawings and

43 A. Söderlund, written commentary.

44 AA. K15/46/1/9/3, Project Japonica, Minutes of the seventh meeting of the project coordination committee held at Naval HQ, 21 October 1976, p.5, J.R.W. Dart (Project Leader Armaments Board/Armscor project team in Israel), interview, 1986, and A.G. Söderlund, written commentary, September 2004.

45 AA. CK15/46/30/5. Report by Cdr J.R.W. Dart on the Argus area of activities with respect to Project Japonica, 1 April 1975 - 30 June 1978, 12 July 1978, pp.9, 12-13. See also Potgieter, pp.163-65. 
technical information it was frequently in Hebrew and had to be translated. ${ }^{46}$ After the building phase in South Africa commenced, officials from Armscor and Sandock Austral often visited Israel, gaining much information personally.

Crucial to naval shipbuilding programmes are a series of tests on the vessels and equipment to prove that the vessels conform to the contract stipulations, applicable plans and specifications. These tests, referred to as the acceptance trials, include all the tests during the building of the vessels and the installation of equipment as well as the harbour and sea acceptance trials. In Israel the Naval Acceptance Group (NAG) that had to design and approve these trials were under the control of Cdr Dart and consisted of both Armscor officials and SAN officers. ${ }^{47}$ On all three ships the sea acceptance trials took longer than initially anticipated (about six days instead of three), but after problem areas were rectified, the ships were accepted and handed over to the SAMMIDE.

\section{The Undercover Experience: Living and Working in Israel}

Under normal conditions, the establishment of a project team in a foreign country would pose problems. The Japonica project team was exceptional, seeing that it did not only have to cope with a vastly different language and cultural environment, but a very high security classification placed additional demands on its labours. From the first day onwards the team faced many problems. Their initial difficulties were caused by the fact that agreements and contracts that should have been concluded in advance, such as office and accommodation arrangements were still outstanding when they arrived. But, as it was impossible to make such arrangements in the name of the $\mathrm{AB}$, IAI concluded a number of agreements on behalf of the project team where after IAI and the AB had to conclude back-to-back agreements. $^{48}$

Office space was a problem, as the team could not use offices at the South African Consulate. Though IAI undertook to make office space available at their offices close to the Ben Gurion Airport (Tel Aviv), it was not yet ready when the project team arrived and they had to work from their hotel rooms. In a number of memoranda and letters (some handwritten), Cdr Dart complained bitterly to the $\mathrm{AB}$ Assistant General Manager Navy and Electrical (Mr F.J. Bell) and the Manager

46 F.J.Bell (former Chief Executive Armscor and Manager Vessels Division), interview 1987.

47 AA. K15/46/1/9/3, Project Japonica: Minutes of the seventh meeting of the project coordination committee held at Naval HQ, 21 October 1976, p.5 and J.R.W. Dart, interview.

48 AA. F.J. Bell Collection, BE5/1, Volume 1, Memorandum Dart - Bell, Memorandum of Agreement, 28 September 1975. 
Vessels Division (Mr W. Venter) about the problems they experienced in establishing the project team. ${ }^{49}$

IAI also provided four offices at the shipyard (ISL at Haifa) and agreed to erect a temporary building with offices for the AB project team, the SAMMIDE personnel (12 members besides the crews and men under training) as well as one office per boat. ${ }^{50}$ The process then stalled, and the South Africans experienced a critical shortage of office space. It was only after the problem was addressed at the high level bilateral Israel-South Africa meeting (ISSA), that the building was quickly completed and the office accommodation problems solved. ${ }^{51}$

Private accommodation in the Haifa and Tel Aviv was an important requirement for establishing the project team. But the accommodation was a problem: as they had no offices on arrival they worked from their private hotel rooms, which forced them to regularly move rooms in order to mislead listening devices. ${ }^{52}$ Furnished houses were the best option, but well furnished houses were very expensive and as furnishings were not very good at times, additional furniture often had to be bought. All housing contracts were concluded by IAI on behalf of the $\mathrm{AB}$ and the SAMMIDE. Back-to-back contracts were then concluded and IAI were reimbursed for all the accommodation costs. ${ }^{53}$

In the Establishment Plan provision was made to rent vehicles from Hertz until the project team could acquire its own transport. With the arrival of the AB team members, IAI provided a car for a short period, where after Hertz was used and the project team gained permission to purchase vehicles. ${ }^{54}$. Purchasing vehicles was very expensive due to a heavy tax, and as the South African consulate received a $75 \%$ tax deduction, it was thought that vehicles could be purchased through the consulate. The South African Consul General, however, made it clear that this would not be possible as vehicles purchased tax-free had to carry diplomatic number plates that could be traced to the country that purchased them. In the light of the security restrictions this was not an option. ${ }^{55}$ Another problem was that due to

49 AA. D39/1, Dart - Venter, Project Japonica: Establishment problems locally, p.1.

50 AA. M/6/5/11, Volume 1 , Attachment D to Minutes of the Third ISSA (Israel-South Africa) Meeting, 30 June - 3 July 1975, AA. K15/46/10/2, Project Japonica Settlement Plan, 24 March 1974, p.4 and A. Söderlund, written commentary.

51 AA. CK15/46/30/5. Report by Cdr J.R.W. Dart on the Argus area of activities with respect to Project Japonica, 1 April 1975 - 30 June 1978, 12 July 1978, p.17.

52 AA. D39/1. Dart - Venter, Project Japonica: Establishment problems locally, p.4.

53 I.O. du Toit, interview and AA. BE9/5/1, Volume 1, Establishment and Support of Team in Cane, no date.

54 AA. D39/1, Aankoop van motors vir die Japonica-projekspan in Cane, 13 June 1975.

55 AA. D39/1, Discussion of the settlement problems at the SA Consulate General, 6 April 1975. 
security, the vehicles could not be registered in the name of the $\mathrm{AB}$ and it was against regulations to register official vehicles in the name of officials. As a result a cheaper long-term rental agreement was concluded with Hertz. ${ }^{56}$ In terms of private vehicles the Israeli authorities made a special concession, allowing three vehicles to be imported tax-free. While in Israel some South Africans also bought and sold vehicles on the open market.

The financial management of the project team was the responsibility of the team leader and his staff, who had to report on all expenses and provide a yearly budget. In accordance with the initial Settlement Plan the AB would transfer funds to Foreign Affairs, who would then make payments on behalf of the AB in Israel. Immediately after the arrival of the project team this arrangement proved to be problematic. After a meeting with the South African Consul General in April 1975, it was decided that they would transfer funds into the account of the AB. But this posed a security problem as the South African Consulate (later embassy) was not to be directly involved with the activities of the project team. ${ }^{57}$

Bank accounts posed another problem, as security concerns prevented an account being opened the name of the $\mathrm{AB}$. Two accounts were then opened; the $\mathrm{AB}$ account was in the name of Messieurs Dart, Du Toit and Cook, while the SAN account was in the names of Messieurs Orrock, Du Plessis and Butler. The Consulate then transferred funds to the relevant accounts, while the financial and administrative personnel took responsibility for paying salaries, accommodation, travel expenses and other accounts. ${ }^{58}$ Later, funds were not channeled through the South African diplomatic mission, but were directly paid to the Israeli Ministry of Defence (MoD) who then transferred it into the various accounts.

The financial control was still a cause for concern, as the accounts would be frozen if something happened to one of those in whose name the accounts were. As state funds could be affected if a claim was made against one of the members and the danger of the official link still existed a special "cover company" with the name Camery (Ltd) was created in March 1976. The Israeli Ministry of Defence organised for it to receive special concessions in terms of registration and taxes, with the result that a legal company existed that could conclude lower level contracts and

56 AA. CK15/46/30/5, Report by Cdr J.R.W. Dart on the Argus area of activities with respect to Project Japonica, 1 April 1975 - 30 June 1978, 12 July 1978, p.17.

57 I.O. Du Toit, interview and AA. K15/46/10/2, Project Japonica Settlement Plan, 24 March 1974, pp.5-6.

58 AA. D39/1. Discussion of the settlement problems at the SA Consulate General, 6 April 1975 and CK15/46/30/5, Report by Cdr J.R.W. Dart on the Argus area of activities with respect to Project Japonica, 1 April 1975 - 30 June 1978, 12 July 1978, p.16. 
provide the mechanisms for effective financial management of the project team. ${ }^{59}$ Unfortunately this company was only created a year after the arrival of the project team and at this stage SAMMIDE already did business in Haifa as SAMMIDE. The Bank was well acquainted with the arrangements of Messieurs Dart, Du Toit and Cook and since funds were channeled through the Israeli MoD, no questions were asked. However, if the above arrangement were made earlier, it would have solved many problems.

Salaries of the project members were initially paid in Israeli Lirot, but since the cost of living was very high, the money depreciated quickly and they received no tax concessions, members of the project team were finding it financially strenuous. For a short period they received half their salaries in Lirot and half in US Dollar, but it was still problematic due to the depreciation of the Lirot. ${ }^{60}$ After treasury approval was granted, project team members received their salaries in US Dollar from the last quarter of 1976 onward. This arrangement was much better, due to the higher value of the Dollar. ${ }^{61}$

Many of the frustrating administrative problems that members experienced related to customs and taxes on official and private property. In some cases this took a very long time to solve and it seemed that little official preparations were made by the Israeli authorities to accommodate the project team. ${ }^{62}$

In terms of legal advice, the Israeli legal system has a Turkish-Roman base, which made sound legal advice a necessity. The South African Consulate suggested that the project team approaches their legal advisor, advocate Abe Goldin, who had a security clearance from both the Israeli MoD and South Africa. ${ }^{63} \mathrm{He}$ was of much service to both the AB project team and SAMMIDE and assisted with contracts, the "cover company", accommodation and monetary transactions. He often warned about pitfalls and also acted as arbiter when differences arose between the South Africans and Israelis. ${ }^{64}$ Though his service was expensive his assistance was

59 AA. BE9/5/1, Volume 1, General Manager to Assistant General Manager: Spesiale Maatskappy Cane, 2 April 1976 and BE7/1/4, Maatskappy in Cane, no date.

60 A. Söderlund, written commentary.

61 AA. BE9/5/1, McGee - Bell : Plasing van beamptes in Cane, 7 October 1975 and K15/46/30/5, Volume 1, Appendix A to Visit to Cane by F.J. Bell and W. Venter, 2123 July 1975 , p.2.

62 AA. K15/46/10/3, Volume 1, Progress Report 2/75: Establishment of a team in Cane, 29 April 1975 and K15/46/30/5, Volume 1, Appendix A to Visit to Cane by F.J. Bell and W. Venter, 21-23 July 1975, pp.2-5.

63 MAD. SAM10/66/2/1/11, Letter Orrock - Military Attaché, 26 February 1976.

64 AA. CD39/32/2. Numerous letters were written by members of the project team to the General Manager Commercial, regarding the legal advice given by Advocate Goldin, August-September 1977. 
extremely valuable due to his knowledge, experience and influence. He often placed the interest of the South Africans first, warning them about possible dangers and as Cdr Dart stated, “... without Advocate Goldin's assistance... the situation... in Israel would have been bleak." 65

Security issues impacted fundamentally on the project team in Israel. In a secret agreement between South Africa and Israel (February 1976) it was decided that the relationship between South Africa and Israel must be kept secret. A working procedure was established with rules for the protection of information and equipment, co-ordinating methods were agreed upon and the responsibilities of the security personnel of the two states were defined. Provisions were also made for the handling of post and telex messages; the dispatching, loading and protection of equipment; the removal of trade names on equipment; and the use of encoded names. ${ }^{66}$ Hence the relationship between Israel and South Africa was cloaked in secrecy and high project security was priority. Everything had to be done in a specific prescribed way. Initially all documentation relevant to the strike craft project had a "Top Secret" classification, which made it very difficult to handle documents. Later this was changed to "Secret".

The establishment of the project team with their families in Israel was perceived as a big risk, but a good cover story was seen as the solution. ${ }^{67}$ The initial cover story was that the project team was investigating the possible building of a container ship in Israel. This was credible enough, but when two officials of the AB at an early stage of the project visited the gun factory in Italy to view its facilities, the Israelis were convinced that it caused a security breach and the initial cover story was thought not to be credible anymore. ${ }^{68}$ Some naval members posed as students, but it was also at times difficult to keep to the cover story. ${ }^{69}$ In May 1975 it was decided to change the cover story, and on the request of IAI the project team were referred to as immigrants working for IAI. ${ }^{70}$

\footnotetext{
65 AA. CK15/46/21/4, Dart - Military Attaché, Project Japonica in Israel, Legal Advice, 21 February 1976, p.2.

66 AA. BE9/5/1, Volume 1, Procedure for Co-ordination and Definition of Fields of Responsibility between the Security Authorities of Israel and South Africa regarding the Protection of Classified Military Procurements and the Exchange of Classified Information, 2 February 1976, pp.1, 7, 8.

67 MAD. VSH10/66/2/1, Projek Japonica: Notule van 'n vergadering om sekerheidsprobleme te bespreek, 6 February 1976, p.6.

68 AA. K15/46/30/5, Volume 1, Appendix A to Visit to Cane by F.J. Bell and W. Venter, 21-23 July 1975, p.5.

69 A. Söderlund, written commentary.

70 AA. K15/46/1/9/3, Project Japonica: Minutes of the third Co-ordination meeting held at Naval HQ, Simonstown, 22 May 1975, p.6.
} 
Despite all the restrictions, security breaches did occur with the media reporting on the project. On 8 March 1976 the Jerusalem Post reported that strike craft with Israeli Gabriel II missiles were to be built under license at SandockAustral in Durban. ${ }^{71}$ On 7 August 1976 the Pretoria News reported that according to Radio Israel, Israeli shipyards were building two vessels armed with Gabriel missiles for South Africa and that a project team and their families were in Israel to receive training. ${ }^{72}$ In accordance with the agreement none of the governments reacted.

In August 1976 the South African Ambassador in Israel noted with concern that reports are surfacing about Israeli-South African defence co-operation. It was suggested that South Africa provided resources to Israel in exchange for weapons. The issue was apparently also discussed in the Knesset when a member of the Communist Party posed a question to the Minister of Defence. The minister did not answer. The South African Embassy received many enquiries, both diplomatically (for example from the USA), and from the media, but never admitted to any of the transactions. ${ }^{73}$

Politically South Africa and Israel were both under attack and President Sadat of Egypt reportedly referred to a Tel Aviv-Pretoria axis created to terrorise the Arabs and Africans with nuclear weapons. During meetings the Israelis often expressed their concern about security issues and asked the South Africans to be careful and not to provide their enemies with more ammunition ("bykomende skietgoed aan ons vyande in hul propaganda-kampanje"). ${ }^{74}$ As a result security on the project was maintained at a high level.

In terms of their personal life, project team members and their families had to adapt to the security restrictions. One of the first things to suffer was personal communication. Post could not be directly sent to Israel, but had to be posted to a Private Bag in Pretoria. The receivers' name could not be written on the outside envelope, but on an inner envelope. The post was then taken with the diplomatic bag and then posted to the recipients as the South African Embassy were not directly associated with the project team. In practice this system did not work well and often families did not receive post for up to six weeks - one Christmas without post from home was particularly bad for the South Africans in Israel. A SAMMIDE member

71 AA. BE9/5/1, Volume 1, Telex, Military Attaché Israel - to Chief of Staff Intelligence, 15 March 1976.

Pretoria News, 7 August 1976.

AA. BE9/5/1, Volume 1, Ambassador Israel - Secretary of Foreign Affairs: Israel/Suid-Afrikaanse Samewerking op Militêre Gebied, 17 August 1976.

74 Ibid. 
later regularly picked up post at the SA Embassy. ${ }^{75}$ Problems associated with the handling of post were mainly in South Africa and not in Israel and according to Cdr Dart this was more damaging to the morale of the families in Israel than any of the other restrictions. $^{76}$

As regards education for the children of the project team, sending them to Israeli schools was not a good option. In Tel Aviv there was a good (and expensive) American school, but as it was $130 \mathrm{~km}$ from where most South Africans stayed (in Haifa), it would be difficult in the Israeli climate to use a bus on a daily basis. During the Third ISSA meeting in (June-July 1975) Admiral Bierman (Chief of the South African Defence Force) requested permission from the representative of the Israeli MoD, Mr Ironi, to establish a school for the South African children. The Israeli answer was that it could be allowed if it would not pose an additional security risk. ${ }^{77} \mathrm{AB}$ and SAN personnel were in favour of creating a South African school, as it would be possible to follow a South African curriculum. Adv Goldin was asked to assist with finding the right building. Goldin managed to secure the building attached to an Israeli agricultural school at Kuvar Galim (10 km from Haifa) and a contract for a three-year period commencing on 1 January 1976 was concluded. ${ }^{78}$ The South African Minister of Interior Affairs granted permission to use two teachers from the Cape Provincial Administration (Mr and Mrs F. Steynberg) and a third teacher (Ms Walters) would later follow. The school followed the curriculum of the Cape Provincial Administration from Sub A to Standard Five and at its height it had 70 learners. It closed on 5 February 1978 as the repatriation of the South Africans commenced. ${ }^{79}$

Many South African families experienced problems with adapting to the social and living conditions in Israel during the initial phases of the project. South Africans often experienced difficulties with the legal and bureaucratic environment, and initially they considered the Israelis to be stiff and impolite. Later, they realised that their hosts had a different approach and with the assistance of the public relations personnel of IAI, who did much to make South Africans feel welcome, people adapted better and integrated socially. Though the Jews do not celebrate

75 A. Söderlund, written commentary.

76 AA. CK15/46/30/5. Report by Cdr J.R.W. Dart on the Argus area of activities with respect to Project Japonica, 1 April 1975 - 30 June 1978, 12 July 1978, p.18.

77 AA. M6/5/11, Volume 1, Appendix D to Minutes Third ISSA Meeting, 30 June -3 July 1975, p.5.

78 AA. K15/46/30/5, Volume 2, Report on overseas visit by Messrs W. Venter (Vessels), B.F. van Niekerk (Administration) and C.H.M. de Beer (Vessels) to Cane and France, 9-21 November 1975.

79 J.S. Orrock, interview and AA K15/46/10/2, Project Japonica, Withdrawal Phase, Personnel, 26 January 1978, pp.1-3. 
Christmas, personnel from IAI for example even provided Christmas trees to the South Africans.

Even simple tasks such as shopping could pose difficulties due to language and cultural differences and the fact that many consumer articles the South Africans were used to were not available. Furthermore consumer goods were very expensive which made it difficult, as members of the project team could not apply for loans and had to purchase everything in cash. Many South Africans however soon became accustomed to the local conditions and consumer goods, and specifically those that picked up basic Hebrew found it easier to integrate, live and work. ${ }^{80}$

Socially project team members sometimes experienced difficulties due to questions they were asked and the fact that reporters at times harassed them. Many members of the project team also had contact with diplomats and representatives of other states and at times it was clear that though some knew the reason for the South African presence, they did not discuss it socially. ${ }^{81}$

Language added to the list of problems, both socially and at the workplace. Though the top structure of IAI was fluent in English, in the industry and in the IN, Hebrew was the most common language. Orders as well as all tallies, instructions and documents were in Hebrew, with the result that many members of the project team did a basic course in Hebrew with a special emphasis on Hebrew seamanship terms. In the end, many of the members spoke Hebrew fluently.

Unmarried naval personnel detached to SAMMIDE lived in hotels, but as the various ranks were not to be mixed in the true naval custom, officers and ratings stayed at hotels in different parts of town. ${ }^{82}$ They wore no uniforms, did not have regular rounds as is the custom in the Navy and instead of using ranks when addressing each other, they used the terms "sir" or "mister". Despite doing away with these naval customs no serious disciplinary difficulties were experienced and there were also no problems in the relationship with locals.

An aspect that caused tension amongst naval members is the fact that when delays were experienced in the delivery of the strike craft, the families of some of the navy members had to return, while some of the families of Armscor members stayed longer. Some navy members felt that double standards applied. These and

\footnotetext{
80 A. Söderlund, written commentary.

81 Information concerning the Israel experience was to a great extend gained from interviews conducted with a number of project team members and other Armscor and SAN personnel, including F.J. Bell, I.O. Du Toit, W. Venter, J.S. Orrock, J. Swanepoel, J.R.W. Dart and R.C. Simpson-Anderson. 
other discrepancies created some tension between the Navy and Armscor that would also impact on the local building phase of the project. ${ }^{83}$

For the married team members their families were very important, as the Armscor project leader Cdr Dart stated in his report: "Israel is not the easiest country to live in and under the strict security classification of the project, family life was a most important consideration. ${ }^{, 84}$ Though many difficulties were experienced, South Africans and their families generally coped well and members involved agreed that much was done to make them feel at home. At the workplace the situation was much the same and though South Africans and Israelis often differed severely from each other, it never became big disputes. Generally co-operation was good between the South Africans, the contractors and the Israeli population, making the experience bearable and at times even pleasant. ${ }^{85}$

\section{Vessel Delivery and the Completion of the Project}

As agreed with the Israeli authorities, there was no ceremony with the launching of any of the three strike craft due to political and security considerations. Mrs Annette Rennie (wife of the Officer Commanding of the third vessel and a member of the SAMMIDE staff) launched the first strike craft (P1561) on 18 February $1977{ }^{86}$ At this stage there was some tension between the Israelis and South Africans as all the equipment were not yet delivered and the South Africans wanted ISL to first rectify a number of problems before the vessel could commence with its acceptance trials. As a result tests had to be done with the assistance of equipment (such as the optical director) borrowed from the IN.

Due to the many corrections made and the reinstallation of much of the equipment on the first strike craft, a number of plates had to be removed and fitted again, with the result that the vessel received the nickname "Patches." The second vessel was nicknamed "Scratches" while as a result of the tendency to fix (sometimes poorly) and pass on previously rejected items to the next strike craft it was called "Matches."

Cdr Dart and the NAG worked hard to create appropriate standards and a set of criteria against which to test the vessels. Despite a wide variety of problems experienced, the acceptance trials were completed during July 1977. Yet, the vessel still had an IN optical director onboard, which had to be handed back before it

83 Potgieter, pp.145 and 205-211.

84 AA. CK15/46/30/5. Report by Cdr J.R.W. Dart on the Argus area of activities with respect to Project Japonica, 1 April 1975 - 30 June 1978, 12 July 1978, p.21.

85 Interviews with numerous members of the project team, see footnote 73.

86 AA. K15/46/10/3, Telegram, SAMMIDE to Navchief, 21 February 1977.

87 A. Söderlund, written commentary. 
departed for South Africa. In the end the optical director arrived and was installed during July/August. ${ }^{88}$

The P1561 was commissioned in August with Cdr R.C. Simpson-Anderson as Captain and immediately had to prepare for the long voyage to South Africa. The South African and Israeli authorities felt that, even if the possibility was extremely remote, one had to consider the possibility of the ship being hindered or even attacked on its voyage. Therefore it was decided that ships of the Israeli Navy would escort it to Gibraltar. On 25 August at 21:00 the P1561 left Haifa on its 7000 mile voyage to South Africa. It flew the Israeli flag (the SAN ensign was only hoisted after arrival in South Africa) and was escorted by two IN vessels to Gibraltar. Because of the limited range of a strike craft, the P1561 had to be replenished en route. Since it was not possible to enter African ports, replenishment had to take place at sea and at a pre-arranged point in the Atlantic (away from busy shipping routes), the P1561 and the SAS Tafelberg rendezvoused twice, for the much-needed replenishment. ${ }^{89}$

The second strike craft (P1562) was launched on 9 September 1977. But, before it was handed over to the SAN, the UN Security Council instituted its mandatory armaments boycott against South Africa on 4 November 1977. This impacted severely on naval acquisition programmes as France immediately cancelled two vessel projects. In Israel, the project team anxiously awaited Israeli reaction. Representatives of the Israeli MoD suggested on 14 November that the South Africans might have to depart with the second vessel, even though it was still incomplete. ${ }^{90}$ The project briefly continued, but shortly afterwards it was agreed with the Israeli authorities that P1562 (with Cdr E.I.B. Massey-Hicks as Captain) would have to sail for South Africa at an earlier date (6 December 1977). There was still a list of outstanding items on the vessel, but it had to be finished in South Africa. On the evening the P1562 sailed, only its Officer Commanding and three of the officers were aware that they were going home and were not conducting trials. Four wives and families of P1562 crewmembers were still in Israel and were scheduled to leave by middle December. They were informed that their husbands were on their way to South Africa after the vessels sailed and had to pack up themselves. $^{91}$

88 MAD. VSH10/66/2/1, Projek Japonica, Vertrek van eerste vaartuig, 20 April 1977 and Notule Japonica-projekvergadering, 8 September 1977.

89 AA. CK15/46/30/5, Report by Cdr JRW Dart on the Argus area of activities with respect to Project Japonica, 1 April 1975 - 30 June 1978, p.9.

90 MAD. Minutes of the ninth meeting of the Project Co-ordinating Committee held at NHQ on 16 Nov 77, p.4.

91 A. Söderlund, written commentary. 
The third vessel (P1563) was launched on 15 January 1978 and was completed in a tense atmosphere as the Israeli armed forces were placed on alert due to the civil war in Lebanon. ${ }^{2}$ It was suggested that the P1563 should also depart earlier, but the Chief of the SAN insisted that it should not depart before the completion of all outstanding work on it. On 24 February the P1563 was placed on alert and had to be ready to depart within 24 hours. Eventually the vessel was delivered fully equipped on 6 April and departed for South Africa on 14 April with Cdr M.A. Rennie as captain.

\begin{tabular}{|c|c|c|c|c|}
\hline Vessel & $\begin{array}{c}\text { Launch } \\
\text { date }\end{array}$ & $\begin{array}{c}\text { Contractual } \\
\text { acceptance date }\end{array}$ & $\begin{array}{c}\text { Final acceptance } \\
\text { date }\end{array}$ & Departure date \\
\hline P1561 & 18 Feb 77 & 21 Oct 76 & 8 Jul 77 & 25 Aug77 \\
\hline P1562 & 9 Sep 77 & 21 Feb 77 & 30 Nov 77 & 6 Dec 77 \\
\hline P1563 & 15 Jan 78 & 21 Jun 77 & 6 Apr 78 & 14 Apr 77 \\
\hline
\end{tabular}

Figure 3: Summary of the delivery schedule of the first to third vessels.

The transfer of know-how from Israel was crucial for the local building programme as it was the first time complex warships were built in South Africa. Many problems were experienced with the transfer, flow and understanding of know-how. Construction on the first locally built strike craft (P1564) started late in 1975, and it was launched on 15 September $1978 .{ }^{93}$ The other two local strike craft (P1565 and P1566) were launched on 16 March and 28 September 1979 and started service with the SAN in July 1979 and March 1980 respectively. The new strike craft were named the Minister of Defence Class and were given the names of previous South African Ministers of Defence.

By the time Project Japonica reached completion, none of the corvette programmes of the SAN had survived. More vessels were needed due to the operational requirement of the SAN. Furthermore, as the local shipbuilding capacity was regarded as of strategic importance to South Africa, it had to be maintained. As a result, a follow-up programme (Project Coupé) to locally build two more strike craft came into being early in 1978. ${ }^{94}$ Both vessels were launched during 1982 and commissioned in 1983. During the early eighties a new project to built four more

92 AA. CK15/46/30/5, Report by Cdr J.R.W. Dart on the Argus area of activities with respect to Project Japonica, 1 April 1975 - 30 June 1978, 12 July 1978, p.11.

93 Du Toit, p.300.

94 Potgieter, pp.257-58. 
strike craft was instituted and quickly cancelled. It was then replaced by another project for the ninth (and last) strike craft. Its purpose (in conjunction with the building of the SAS Drakensberg) was also to keep the local shipbuilding facility going. This strike craft, P1569, was delivered to the SAN during July 1986.

Besides the problems experienced, in the whole the overseas building phase went well. The project was nine months behind schedule, mainly because of the contractor's inability to stick to time-scales, insufficient quality control and the late delivery and installation of some of the electronics and weapon systems on board. The armaments boycott, though it caused some anxious moments, did not jeopardise the strike craft project. The strike craft project also had far-reaching importance for South African industry, as technologically advanced and complex ships were locally constructed (under licence) and delivered to the SAN. However, this ability does not exist anymore.

\section{Conclusion}

During much of the history of the SAN, its shortage of warships (also linked to financial difficulties) was a major problem. Originally it acquired warships from Britain, but due to South Africa's apartheid policy, this was no longer possible from the middle sixties onwards. The international political situation and the condemnation of South Africa had a severe impact on the corvette and frigate acquisition projects of the SAN. A project to build corvettes in Portugal was cancelled in 1974 due to the changing international situation, while the compulsory UN armaments boycott of November 1977 caused the cancellation of two French projects of the SAN (a corvette and a submarine project). The UN embargo also placed the strike craft project (current at the time) in the balance, but in the end it did not lead to its cancellation. As a result, the strike craft project (Project Japonica) is therefore unique, as it was the only project covering surface combatants for the SAN that reached fruition over a period of almost four decades. When all the frigates and destroyers of the SAN were taken out of service, the strike craft remained as the Navy's main surface combatants.

Under Project Japonica six strike craft were completed (three were built in Israel and three locally). Managing the project in Israel was often difficult due to problems emanating from the strict security and the different environment in which the project team had to work and live. The Israeli built vessels were delivered at intervals of about four months, but deliveries were about nine months later than stipulated in the original agreement. These delays could be ascribed to various reasons, of which the most important are the quality control problems experienced, the late delivery of equipment that had to be installed, as well as to the inability of ISL to keep to the original timescales. 
On the whole, the overseas building phase went well and if it is measured against its original objective of obtaining strike craft for the SAN as a "package deal", it was a success. Despite difficult conditions and the strict security limitations placed on the project team, they managed the project well and contributed largely to the success of the overseas building process. Vessels were acquired with the minimum of changes to the original design, the know-how was obtained to locally produce warships (under license) and the whole undertaking was successfully completed. The first strike craft was taken into service by the SAN only three years after the contract with IAI was signed (in August 1974), while by March 1980, the SAN had received all six of the Japonica vessels. Three additional locally built strike craft would be commissioned into the Navy during the nineteen eighties.

With the commissioning of the strike craft, the SAN was propelled into the missile era, as it was their first ships armed with missiles and they had to learn to manage the sophisticated electronic systems that went with it. Furthermore, despite the inherent limitations of these vessels in terms of their size, sea keeping and armament, they served the Navy with distinction for decades and were indeed "maids of all work", during a very difficult era in the history of the SAN.

Scientia Militaria, South African Journal of Military Studies, Vol 32, $\mathrm{Nr} 1,2004$. http://scientiamilitaria.journals.ac.za 